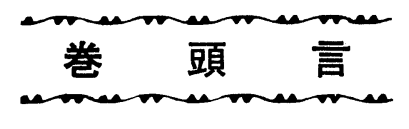

\title{
アフリカに於ける医学研究の必要性について
}

\section{長 谷川秀 治*}

私がアフリカ大陸の視察旅行をしたのは, もら 10 年も前の事であるが, その後も日本アフ リカ学会の会長として, アフリカに関する記事はたえず心がけて読んでいるので, 大体の知識 は持っているつもりである，何分日本の 80 倍の面積をもっている大陸であり, 豊富な資源に 恵まれ, 発展途上にある数多くの国々には多種多様の民族が住み, 言語, 風俗, 習慣も異なる ので，簡単に何事も述べる事は困難であるが，特に研究の急を要するのは，保健衛生に関する 医学方面の研究ではあるまいかと思う.アフリカの大都市のみを旅行する人々にはマラリア等 はほとんぞ心配ないかの如くに言われているが，それでも 1 年中に 2,3 例は日本に帰国後, 悪性マラリアを発病し，また最悪の場合は入院中に死の転帰をとる者さえある事を耳にする. 予防薬は必ず服用するよら言われても, 我が国にはアルコールは殺菌作用があるから酒さえ飲 んでおれば安全である等の暴論をとなえて, 予防薬を用いよらとしない人がある.このような 人の中から前記の例が出て来る事がある事は充分傾聴に值する. 何分ダイヤとマラリアの国と か, 富と病の遺産の大陸, 等と言われるアフリカの研究は今後, ますをすなされなければなら ないのに, 我が国におけるアフリカ研究は大変おくれているのが現状であろら.しかしその中 にあって, 10 年前に我が日本アフリカ学会が創設されて, 人文科学, 自然科学の各方面から, 毎年発表される論文を通じて日本のアフリカ研究は次第に進歩していると思われる. 諸外国, 特にアメリカ, ソ連等のアフリカ研究は実に膨大なるものである事を聞くにつけ, 経済大国を 自負する日本としてその研究は是非しなければならない急務の一つである. 幸い, 長崎大学熱 帯医学研究所に括ける第 8 回日本アフリカ学会学術大会で, 「アフリカにおける原始医療と近 代医学」と題するシンポジゥム (座長・片峰教授) が開催され, その時に発表された貴重な論文 を中心に, 今回, 医学特輯号として出される運びになった事は誠に結構な事である. また近時 我が国の多くの医科大学を中心に熱帯医学の研究が盛んになり, 東南アジアを手始めに, イン ドに及び，さらにアフリカに及んで来た事は喜ばしい現象である. 我が国の医学水準はすでに 世界的最高水準に達している事は自他共に認めるところであるのに, アフリカに対する研究が 世界水準よりおくれていた事は遺憾の極みであるが今後の努力に大いに期待している．顧みる とアフリカにおける最も困難であった研究の一つに黄熱があり, この研究はすでに今から 44 年前, 野口英世博士が黄熱病研究のため, アフリカのガーナに扎いて殉職された事はあまりに も有名である. その後, 野口博士の研究が基礎となって, その門弟であったロックフェラー財 団研究所のタイラー博士により, 膨大な研究費を投じて, 黄熱に対する予防ワクチンが作られ, この効果が実に劇的であるために, あの恐れられた黄熱病が今やアフリカから姿を消さんとし ている. 実にアフリカに打る医学研究の黎明の燈火を初めてつけたのは日本人野口英世博士 であった。 もし黄熱ワクチンがなかったならば,アフリカは未だに暗黒に閉されていたであろ ら事を思う時, アフリカにおける医学の研究こそ, 実に緊急を要するものといえるであろう.

*日本アフリカ学会々長 